\title{
THE FUTURE OF LAW SCHOOL: THREE Visions AND A PREDICTION
}

\author{
H.W. ARTHURS*
}

In this article, the author examines three visions of the future of law schools. The first vision is that they should focus on producing "practice ready lawyers" to meet the immediate needs of today's legal profession. The second is that law schools should focus on training "tomorrow's lawyers," graduates who are able to adapt to a rapidly-changing world. The third insists that law schools are knowledge communities whose many functions include, but are not limited to, providing students with a large and liberal understanding of law that will prepare them for a variety of legal and non-legal careers and for participation as citizens in the broader economy and polity. Although the future of law schools is contested and uncertain, the author predicts, law schools will be celebrated in the long term for their distinguished scholarship, their contributions to the public good, and their role as agents of change rather than for skills training, their influence on day-to-day legal practice, and their purveying of conventional wisdom.
L'auteur de cet article examine trois visions des écoles de droit de demain. Dans la première, l'école se concentre sur la production «d'avocats prêts à pratiquer», c'est-à-dire des avocats répondant aux besoins immédiats de la profession juridique d'aujourd'hui. Dans la deuxième, l'école se concentre sur la formation «d'avocats de demain», c'est-à-dire des diplômés capables de s'adapter à un monde changeant constamment. Dans la troisième vision, l'école devient une communauté de savoir dont les nombreuses fonctions incluent, sans toutefois s'y limiter, la prestation aux étudiants d'une compréhension vaste et libérale du droit les préparant à des carrières juridiques et non juridiques afin qu'ils puissent participer en tant que citoyens à une plus grande scène économique et politique. Bien que l'avenir des écoles de droit soit contesté et incertain, l'auteur prédit que ces écoles seront à l'honneur à long terme pour leur remarquable mission professorale, leurs contributions au bien public et leur rôle en tant qu'agent de changement plutôt que pour leur formation de compétences, leur influence sur la pratique juridique au jour le jour et leur prestations d'acquis et de fondés.

\section{TABLE OF CONTENTS}

I. INTRODUCTION . . . . . . . . . . . . . . . . . . . . . . . . . 705

II. VISION 1: TRAINING TODAY's LAWYERS ................ 706

III. VISION 2: TRAINING TOMORROW'S LAWYERS $\ldots \ldots \ldots \ldots \ldots \ldots \ldots 708$

IV. Vision 3: The LaW SCHOOL AS A KNOWLEdge Community . . . . . . 710

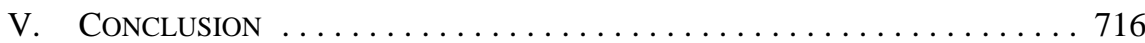

\section{INTRODUCTION}

The future of law school depends on many developments that are largely beyond anyone's control - developments in political economy, technology, demographics, and society that are reconfiguring the legal system, the market for professional services, and the structure of higher education. However, one crucial factor is very much within the control of law schools: the values they embrace and the way they define their ambitions. How they do so will determine whether law schools collaborate with or resist, succumb to or transcend, the powerful forces that I have mentioned. It will determine whom they hire as faculty members and admit as students, what and how they teach, the standards they use to measure 
achievements, and the way they allocate their scarce resources. And crucially, it will determine how, if at all, law schools exploit their strategic location as producers and distributors, as conservators and critics, of legal and social knowledge.

In this article, I present three quite different visions of what law schools ought to be and do. The first sees their primary, if not their sole, function as producing "practice ready lawyers" for today's profession. The second proposes that they should produce "tomorrow's lawyers," lawyers with the capacity to adapt to the rapidly and radically changing circumstances of legal practice. And the third insists that the leading role played by law schools in the creation and transformation of legal knowledge, legal practice, and the legal system requires them to provide their students with a large and liberal understanding of law which alone will prepare them for a variety of legal and non-legal careers and for participation as citizens in the broader economy and polity. I conclude by predicting which vision represents the most likely future of law school.

\section{VISION 1: TRAINING TODAY’S LAWYERS}

I begin with the widely-held view that law schools exist to produce practice ready lawyers. This view is clearly held by the Federation of Law Societies of Canada (FLSC) and its member bodies which recently — for the first time ever, but without stated rationale or clear legal authority — decreed that law schools must ensure that all their graduates are ready to practice. ${ }^{1}$ Unfortunately, producing practice ready lawyers is something law schools cannot do. The problem is that no one knows what practice ready lawyers look like. We lack information about what legal practitioners do, what knowledge or competencies they actually need or use, what breadth and depth of knowledge qualify new graduates as "ready" to practice, or how long they will remain "ready" before what they learned at law school becomes obsolete. ${ }^{2}$ These are empirical questions. However, they were neither asked nor answered before the law societies adopted their new regulations. ${ }^{3}$ (To its credit, the FLSC has attempted to subsequently validate its earlier conclusions by conducting a survey of the

Task Force on the Canadian Common Law Degree, Final Report, October 2009 (Federation of Law Societies of Canada, 2009), online: Federation of Law Societies of Canada <http://www.flsc.ca/_ documents/Common-Law-Degree-Report-C\%281\%29.pdf> [FLSC Final Report]. "[T]he Task Force proposes a national requirement expressed in terms of competencies in basic skills, awareness of appropriate ethical values and core legal knowledge that law students can reasonably be expected to have acquired during the academic component of their education” (ibid at 4). The Task Force recommendations have now been adopted by the FLSC and by all of Canada's common law governing bodies. Law schools must demonstrate that they will be in compliance with the new requirements as of 2015.

2 See Robert J Condlin, “'Practice Ready Graduates’: A Millennialist Fantasy” (2014), online: Social Science Research Network <http://ssrn.com/abstract=2316093>.

3 Supra note 1. The FLSC Final Report cites no empirical evidence to support either a critique of the practice-readiness of current graduates, or its recommendations that all future graduates must possess specified “competencies.” Presumably it had no such evidence. For a critique of the FLSC Final Report on this and other grounds, see HW Arthurs, "The Tree of Knowledge / The Axe of Power: Gerald Le Dain and the Transformation of Canadian Legal Education,” online: (2012) 8:6 Comparative Research in Law \& Political Economy Research Paper Series 25 <http://www.comparativeresearch.net/>; Harry Arthurs, "Valour Rather Than Prudence': Hard Times and Hard Choices for Canada's Legal Academy" (2013) 76:1 Sask L Rev 73. See also Constance Backhouse, “The 'Approved’ Common Law Degree” (2009) 3 CLEAR 141, online: Social Science Research Network <http://papers.ssrn.com/sol3/papers. cfm?abstract_id=2273748>; Canadian Association of Law Teachers \& Canadian Law and Society Association, "Response to the Consultation Paper of the Task Force on the Canadian Common Law Degree of the Federation of Law Societies of Canada December 15, 2008” (2009) 3 CLEAR 151. 
tasks performed and knowledge used by recent graduates; unfortunately, the survey suffers from very serious methodological shortcomings. ${ }^{4}$ )

That said, we are virtually certain of one fact about the profession: it is fractured along a number of deep fault lines. ${ }^{5}$ Those lines run vertically and divide general practitioners from specialists, specialists from each other, and both from the remaining one-third of law graduates who are employed outside the private practice of law, in government agencies, clinics, or corporate law departments or in non-legal capacities in business, the media, or politics. No less importantly, in private practice the fault lines run horizontally as well as vertically: the profession is stratified. As one descends from higher to lower strata, the clientele tend to become less affluent, the work less complex and more routine, and the rewards more meagre. For these reasons, as one traverses the grid formed by these intersecting vertical and horizontal fault lines, it is almost certain that the scope and depth of what lawyers need to know changes as well.

If this is true, if indeed what lawyers need to know in order to be practice ready varies considerably from one kind of practice to another, it is clear that one size of legal education will not fit all law graduates. But quite inexplicably, Canada's law societies believe that it will. They have recently decreed that, to retain their accreditation, all law schools must ensure that all students acquire all "competencies" and knowledge of all the substantive subjects or fields specified in their new regulations. For that matter, law societies assume that not only all new graduates but all established practitioners know the same things. That is why they allow them to undertake all kinds of work that clients may entrust to them murder trials or IPOs, divorces or patent applications. That is why they do not regularly retest lawyers to ensure they have kept their law school learning up to date, why they do not give them qualified licenses that allow them to practice in some fields and not others, and why they do not, except in very rare circumstances, discipline lawyers for incompetence or ignorance. ${ }^{6}$ It is true that all provincial law societies offer programs of continuing education

See Federation of Law Societies of Canada, National Admission Standards Project: National Entry to Practice Competency Profile Validation Survey Report (September 2012), online: Federation of Law Societies of Canada <http://www.flsc.ca/_documents/NASSurveyReportSept2012.pdf > . Amongst the shortcomings of the Survey are the following: its title suggests that the committee was seeking confirmation of its conclusions rather than formulating its recommendations in response to the data; the response rate (17.2 percent of the sample population) was low; the distribution of respondents did not correspond to the distribution of lawyers across firms, communities, and types of practice; the number of respondents involved in some types of practice was too small to render their responses statistically reliable; the selection of a low threshold for usage of the particular knowledge or skill ("once a month or less") skews the results towards inclusion of virtually everything; the survey did not probe the nature or extent of the knowledge needed in given fields (e.g. use of forms versus conceptual knowledge); and, the aggregation of data, presumably to achieve statistical reliability, conceals potentially important differences amongst subgroups of respondents.

5 Careful, longitudinal American studies document the extent of specialization, how it varies from one community to another, and across firm size. See The NALP Foundation for Law Career Research and Education \& American Bar Foundation, After the JD: First Results of a National Study of Legal Careers (2004), online: American Bar Foundation < http://www.americanbarfoundation.org/uploads/cms/docu ments/ajd.pdf $>$. Stratification and specialization are also tracked in detail and over time in John P Heinz \& Edward O Laumann, Chicago Lawyers: The Social Structure of the Bar, revised ed (Evanston, Ill: Northwestern University Press, 1994); John P Heinz et al, Urban Lawyers: The New Social Structure of the Bar (Chicago: University of Chicago Press, 2005). While Canadian figures may differ somewhat from those in the United States, the general pattern of specialization and stratification is unlikely to do so.

6 Some 85,000 persons are now licensed to practice law in Canada. My analysis of all reported discipline cases in 2011-13 reveals that a total of 23 were disciplined for "incompetence" or "negligence" during a 30 month period. There were two cases in Alberta (in both of which other professional misconduct occurred) and two in British Columbia (one of which also involved misrepresentations). In Ontario, there 
or professional development, some require participation for a given number of hours per year, and a few certify specialists on the basis of their extensive experience and/or training. Nonetheless, to reiterate, the failure of Canada's law societies to institute regular competence tests, discipline or disbar incompetent lawyers, or to issue limited licenses to practice speaks strongly to their willingness to presume all lawyers to be omnicompetent. This presumption, in turn, is what supports their conclusion that all lawyers must know the same things and possess the same competencies, a conclusion that totally ignores the effects of specialization and stratification - the two forces that most powerfully determine what lawyers need to know in order to practice competently.

\section{VISION 2: TRAINING TOMORROW’S LAWYERS}

Law societies have ignored something else as well: the relentless change that is destabilizing existing legal institutions, rules, processes, and patterns of practice. ${ }^{7}$ By contrast, the Canadian Bar Association in its recent Legal Futures Initiative discussion paper identifies the drivers of legal change: technology, politics, economics, and demographics. ${ }^{8}$ We know that family structures, business practices, regulatory technology, forms of property, patterns of social deviance, and strategies of social control are all in flux. Consequently, statutes are amended, common law rules mutate, and legal routines and boilerplates change more frequently and drastically than they used to. The implications for legal education are important. As the CBA's discussion paper notes, “[w]ith the speed of change taking place in the legal environment, choices made at the beginning of a student's course of study may be outdated by the time he or she completes all of the necessary requirements for practice"9 - requirements that were set in stone by Canada's law societies. Some examples of the connections between social change, professional transformation, and legal education follow.

Over three or four decades, globalization has transformed the production of goods and services, corporate structures, the international division of labour, the dissemination of intellectual property and finance capital, and, as a consequence, the norms, modalities and location of many regimes of corporate governance and regulation. In doing so, globalization has also dramatically altered the market for legal services, the structure of the law and consulting firms that deliver those services, the knowledge base of lawyers who advise global businesses, the content of law school curricula, and the focus of legal scholarship. ${ }^{10}$

were 19 reported cases: 11 involved lawyers who negligently allowed themselves to be duped in mortgage or real estate frauds; two involved additional acts of professional misconduct; and only six were straightforward cases of incompetence or negligence. None of these six cases appeared to involve any of the "competencies" or fields of knowledge in which the law societies have made law school instruction mandatory. There were no reported cases of discipline for negligence or incompetence in the other seven provinces.

7

I have reviewed some of these developments and their implications for legal education in a series of articles: HW Arthurs, "Lawyering in Canada in the 21st Century" (1996) 15 Windsor YB Access Just 202; Harry W Arthurs \& Robert Kreklewich, "Law, Legal Institutions, and the Legal Profession in the New Economy” (1996) 34:1 Osgoode Hall LJ 1; Harry W Arthurs, "Poor Canadian Legal Education: So Near to Wall Street, So Far from God" (2000) 38:3 Osgoode Hall LJ 381; Harry W Arthurs, "Law and Learning in an Era of Globalization” (2009) 10:7 German Law Journal 629. CBA Legal Futures Initiative, The Future of Legal Services in Canada: Trends and Issues (Ottawa: Canadian Bar Association, 2013), online: CBA Legal Futures Initiative <http://www.cbafutures.org/ CBA/media/mediafiles/PDF/Reports/trends-isssues-eng.pdf?ext=.pdf $>$ [CBA Legal Futures].

$9 \quad$ Ibid at 34.

10 HW Arthurs, “The Political Economy of Canadian Legal Education” (1998) 25:1 JL \& Soc’y 14. See also CBA Legal Futures, supra note 8 at 38. 
Technology has not only enabled globalization, it has had a direct effect on legal practice. For example, by facilitating the digitization, outsourcing, or offshoring of routine "back-ofhouse" functions, technology has allowed large law firms to reduce their complement of articling students and junior associates which, in turn, has destabilized their business model. By disseminating legal information online, technology has allowed retail purchasers of standard legal services to access self-help sites and permitted online service providers to undercut the lower-tier law firms that formerly delivered such services as part of their core business. And by enabling electronic searches, technology has not only made legal research faster and cheaper, it has blurred the boundaries amongst legal categories and between law and adjacent disciplines. In effect, technology has expanded the bar's territorial reach and intellectual horizons while shrinking its control over the market for legal services. ${ }^{11}$

Now a brief word about demographics. Like the rest of the Canadian workforce, the legal profession is not only aging, it is attracting more women and growing more ethnically diverse. ${ }^{12}$ These developments have had important implications for the deployment, financial fortunes, governance, and education of lawyers. For example, diversity has forced large law firms to embrace meritocracy as a recruitment policy, undermined the image of law as a “gentleman's profession,” and generated pressures for greater democracy in the profession's governing bodies. Meritocracy has also, ironically, converted law schools into gatekeepers, whose badges of “merit" largely decide which graduates will, and which will not, gain access to the most coveted opportunities the profession has to offer. But meritocracy has not completely won the day. Discrimination and prejudice persist. Many highly qualified women feel obliged to leave elite firms for jobs in government and corporate law departments where they find the work environment more supportive. ${ }^{13}$ And students from immigrant and racial minority groups, who often confront economic, linguistic, and social barriers before, during, and after law school, have difficulty finding articling and entry-level jobs and tend to cluster in disproportionate numbers in small, lower-tier practices or as employees of government and other institutions. ${ }^{14}$ These new patterns of recruitment and practice have undermined the bar's traditional reliance on informal socialization as a strategy for instilling professional values in its members. Perhaps this explains why law societies have recently decreed that law schools must instruct their students in "professionalism," a project that the profession itself is no longer willing or able to undertake, underwrite, or even define. ${ }^{15}$

11 These developments, and their long-term implications, have been explored by Richard Susskind in a series of publications. See e.g. Richard Susskind, Transforming the Law: Essays on Technology, Justice and the Legal Marketplace (New York: Oxford University Press, 2000); Richard Susskind, The End of Lawyers? Rethinking the Nature of Legal Services (New York: Oxford University Press, 2008); Richard Susskind, Tomorrow's Lawyers: An Introduction to Your Future (Oxford: Oxford University Press, 2013).

12 See Michael Ornstein, Racialization and Gender of Lawyers in Ontario (Toronto: The Law Society of Upper Canada, 2010), online: Law Society of Upper Canada <http://www.lsuc.on.ca/media/convapril 10_ornstein.pdf > . See also Larry Chartrand et al, "Law Students, Law Schools, and Their Graduates" (2001) 20 Windsor YB Access Just 211.

13 See e.g. John Hagan \& Fiona Kay, Gender in Practice: A Study of Lawyers’ Lives (New York: Oxford University Press, 1995); Joan Brockman, Gender in the Legal Profession: Fitting or Breaking the Mould (Vancouver: UBC Press, 2001).

14 Ornstein reports significant advances in the entry of women, aboriginals, and racialized minorities into the Ontario legal profession, but also the persistence of status and earning differentials between them and other lawyers, especially in older age cohorts (supra note 12 at 34).

15 The situation appears particularly vexed in Ontario. A recent study suggests that in 2011, 91 percent of law firms did not participate in the profession's articling program and 10 percent of all graduates (and 15 percent of visible minority graduates) were unable to find articling positions (Avner Levin \& Asher Alkoby, "Barriers to the Profession: Inaction in Ontario, Canada and its Consequences” (2013) 3:3 Oñati Socio-Legal Series 580). In response, the Law Society of Upper Canada decided to institute (for a three- 
I have tried to show how political economy, technology, and demographics have become drivers of change not only in legal rules and institutions, but in legal practice and ultimately legal education. However, to reiterate, the profession's governing bodies have ignored the challenge of educating lawyers for an uncertain future just as resolutely as they have ignored the need for hard evidence about how lawyers actually practice in a multi-dimensional present. ${ }^{16}$ One thing is certain, however: making graduating students tick all the boxes on an arbitrary list of competencies and fields of substantive law is no way to ensure that they will be practice ready today, much less that they will stay that way for the rest of their careers. By contrast, the CBA's discussion paper addresses the implications of its findings about legal change for law schools, albeit somewhat tentatively. It suggests that "[1]aw faculties should continue to play an important role in teaching the theory of law, legal principles and legal reasoning" and "[w]hile some observers would have them place increased emphasis on the practice of law, law schools in their current form may not be the best option for providing practice training." 17 This suggestion that law schools should focus on "theory..., principles... and reasoning," this scepticism about their role in "practice training," is in part intended to ensure that law graduates have the intellectual tools they need to adapt to the changing, but unpredictable, requirements of legal and other careers. But in part it represents a strong hint that by focusing on what they do best, law schools can make their greatest contribution to the profession.

\section{Vision 3: THE LAW SCHOOL AS A KNOWLEDGE COMMUNITY}

What do they do best? Law schools are knowledge communities: they exist to collect, critique, produce, and disseminate knowledge. We therefore need briefly to consider what we mean by knowledge in the context of law. Obviously the profession is (or should be) as concerned about knowledge as the academy. After all, its monopoly over legal practice rests (somewhat tenuously) on the claim that lawyers know things that other people do not. ${ }^{18}$ However, the profession and the academy relate to "knowledge" differently. Practitioners tend to consume knowledge while academics produce it. Practitioners tend to know what they need to know while academics know what they want to know. Practitioners tend to treat knowledge as a given while academics treat it as contingent, as being constantly revised by

year trial period) a professional training program for students unable to find articles (Articling Task Force, Final Report, October 25, 2012: Pathways to The Profession: A Roadmap for the Reform of Lawyer Licensing in Ontario (The Law Society of Upper Canada, 2012), online: The Law Society of Upper Canada <http://www.lsuc. on.ca/WorkArea/DownloadAsset.aspx?id=2147489848>).

The last data-based (if impressionistic) general surveys of the Canadian legal profession are now a quarter-century old. See HW Arthurs, R Weisman \& FH Zemans, "The Canadian Legal Profession” (1986) 11:3 American Bar Foundation Research Journal 447, revised and republished as Harry W Arthurs, Richard Weisman \& Frederick H Zemans, "Canadian Lawyers: A Peculiar Professionalism” in Richard L Abel \& Philip SC Lewis, eds, Lawyers in Society: The Common Law World (Berkeley, University of California Press, 1988) 123; David AA Stager \& Harry W Arthurs, Lawyers in Canada (Toronto: University of Toronto Press, 1990). As noted by the CBA Legal Futures Initiative, “[p]lanning and decision-making at the industry, firm and individual lawyer levels are hampered by a lack of hard data on the legal industry in Canada.... Without hard information, key decisions are often made on anecdotal information or precedent.... As the market share of the industry declines and excess capacity appears, fact-based decisions will become more and more necessary”(CBA Legal Futures, supra note 8 at 38).

$17 \quad$ CBA Legal Futures, ibid at 34.

18 See e.g. Eliot Freidson, “Theory and the Professions” (1989) 64:3 Ind LJ 423; Herbert M Kritzer, "The Professions Are Dead, Long Live the Professions: Legal Practice in a Postprofessional World” (1999) 33:3 Law \& Soc'y Rev 713. 
new evidence, new methodologies, new theories, and new ways of knowing. Practitioners and academics both need to master non-legal domains of knowledge, but many practitioners are reluctant to admit this, while most academics celebrate interdisciplinarity. And finally, practitioners especially value tacit knowledge, practical knowledge that is gained through experience, disseminated through mentorship, and deployed in response to instinct or reflex, while academics prize explicit knowledge, knowledge that can be systematized, taught, published, and challenged.

It is easy to see, then, that disagreements between the academy and the profession about the nature of knowledge are at the root of disagreements over who should control law schools - the profession's governing bodies or the universities and their law faculties. The future of law schools, I argue, and the future of law as a profession, social institution, and intellectual discipline, depends on who controls knowledge. Law schools cannot function well as knowledge communities if their view of knowledge is disparaged, marginalized, or suppressed because it conflicts with that of the profession; if legal orthodoxy has a privileged place on the curriculum and a pre-emptive claim on resources; if critical scholarship and transformative pedagogy are seen as illicit attempts to subvert professionalism; or if research, graduate studies, and public advocacy come to be seen as derogating from the "true" or "core" mission of law schools or as mere decorative appendages to it.

How should the academy use its freedom to collect, critique, produce, and disseminate knowledge in a world that is in flux, in a legal universe that is increasingly chaotic? First, it is the academy's job to make sense of it all. The academy should therefore chronicle change, identify continuities and discontinuities, demonstrate causes and effects, and explain whose interests and which values are being advanced or attacked. And the academy should wrestle with change. It should advocate for change intelligently when it deserves support and fiercely resist change when it does not. This requires not just intervention at the level of high principle, but practical work such as proposals for new legislation, the conjuring up of new doctrines, and the invention of new instruments of private governance. Moreover, in its engagement with change, the academy must not only chronicle and wrestle with change. It must equip its students - the future architects and artisans of legal change - with the tools and skills they need to implement or respond to change. And finally, as the CBA discussion paper suggests, legal practitioners and policy makers, no less than legal scholars and students, will have to venture into new domains of theoretical and practical knowledge. ${ }^{19}$ Law schools are obvious candidates to lead the way. Academics in adjacent disciplines, experts in government agencies and private consultancies, and leaders in business and social movements all have a great deal to tell us. To engage these "relevant others" in meaningful conversations, lawyers old and new, academic and practicing, must learn to talk to them in their own vernacular. Because knowledge is their special concern, law schools will face their biggest challenge, and can make their greatest contribution, as interpreters and intermediaries, as experts in integrating law-talk with other discourses.

Putting change at the centre of what they do will be hard for law schools - especially with regard to their lawyer training functions. However, they have already made a good start. 
First, law schools have generally abandoned the notion that legal education is only about teaching legal rules. Instead, law schools generally aim to train students to "think like lawyers" - to develop generic analytical and critical skills that can be deployed over time and across a wide variety of legal and non-legal contexts. This is certainly better than insisting, as law societies perversely do, that all lawyers must know the same things. But the current strategy is still somewhat problematic. Perhaps, like pornography, we can recognize "law think" when we see it. However, there is little empirical evidence that all lawyers think alike, that they analyze legal problems in similar fashion, that "law think" necessarily occupies a significant part of their working days, or that lawyers think differently from social workers, literary critics, or corporate executives. Indeed, within legal academic circles, there is a robust debate about what it means to "think like a lawyer." One distinguished legal scholar has recently argued that "[t]hinking like a lawyer is thinking like a human being, a human being who is tolerant, sophisticated, pragmatic, critical, and engaged." ${ }^{20}$ On the other hand, an extensive literature argues to the contrary, that thinking like a lawyer involves a distinctive repertoire of analytical and discursive strategies. ${ }^{21}$ But whichever position one favours, it is important to remember that lawyers who cannot, will not, or do not also think like human beings are quite likely to harm themselves, their clients, the reputation of the bar, and the effectiveness of the legal system.

This leads me to a second strategy — interdisciplinarity — which law schools have been preaching for decades, and sometimes actually practice. Interdisciplinarity takes many forms: joint degree programs, the cross-appointment of scholars from other disciplines to teach law school courses, so-called "law and..." or "perspective” courses and, most commonly, casebook and classroom references to economic, political, sociological, philosophical, and historical perspectives on legal issues. Interdisciplinary teaching is difficult: many law professors are not well-trained or well-read in other disciplines; appropriate materials are sometimes hard to come by; and students are often resistant. However, as I have suggested, most legal academics are convinced that interdisciplinarity is an essential element of the response to change: it shakes lawyers loose from the notion that law is unchanging and unchangeable, it gets them into the habit of thinking outside the legal box, and it helps them better understand just what is in that box. Interdisciplinarity, depending on one's point of view, is either a complement or a corrective to thinking like a lawyer.

A third, related strategy, long ago adopted by law schools, but still resisted by the profession, is the optional curriculum which, apart from a few introductory or foundational courses, allows students to decide what they wish to study. Optionalization is meant to engage students intellectually and, at the same time, to help them to prepare for varied and unpredictable futures. There is not much downside to the optional curriculum. If law schools are primarily teaching students how to think, one subject will serve as well as another. And in fact, the optional curriculum has distinct advantages. Students with different interests and

20 Anne-Marie Slaughter, “On Thinking Like A Lawyer” Harvard Law Today (May 2002), online: Princeton University <http://www.princeton.edu/ slaughtr/Commentary/On\%20Thinking\%20Like\% 20a\%20Lawyer.pdf $>$.

21 The debate centres on the tension between techniques of formal legal argumentation and the cultural and political assumptions embedded in them. For recent contributions see Elizabeth Mertz, The Language of Law School: Learning to "Think Like a Lawyer" (New York: Oxford University Press, 2007); Frederick Schauer, Thinking Like a Lawyer: A New Introduction to Legal Reasoning (Cambridge, Mass: Harvard University Press, 2009). 
career aspirations will sensibly want to study subjects that advance those aspirations. Consequently, optionalization enhances motivation. And there is another advantage: if graduates are going to have to educate themselves during their future careers, in order to adapt to a changing society, economy, and legal system, they must learn to learn. If the optional curriculum is properly structured, it will involve higher level, interdisciplinary, experiential, and capstone courses, as well as research and writing requirements. ${ }^{22}$ Such learning experiences — rather than the Socratic or lecture methods of instruction traditionally used in "core" courses - will help students develop their critical intelligence and their integrative skills, both of which will enable them in later years to seek out and assimilate new ideas and information. And one further point: the optional curriculum gives scholar-teachers an opportunity to use their classroom or seminar room as a testing ground for new ideas and as a conduit for disseminating those ideas to future generations of practitioners and policy makers. Consequently, it is an important vehicle for the renewal of the legal profession and the justice system.

Law schools are increasingly committed to one more important strategy: experiential learning. ${ }^{23}$ They believe that immersing students in real or simulated legal situations has several advantages. Like the optional curriculum, experiential learning enhances motivation. It exposes students to certain intractable facts of legal life - the legal power of deep pockets, the anguish of clients caught up in a system they do not understand, the stultifying effects of déformation professionelle. This exposure can incite students to think critically and systemically, as well as analytically, and convey powerful normative lessons, but is difficult to achieve through conventional course materials and teaching methods. Still, I must add a note of caution: there is a risk that experiential learning can degenerate into mere skills training. Obviously, if students do learn something about negotiation or counselling or advocacy, that is a good thing. However, experiential learning is not simply to show students how to put "law-think" to practical use; it is to enable them to confront the normative, logistical, and relational issues that are immanent in all legal encounters. In this sense, the success of experiential learning depends ultimately on the strength of law schools as knowledge communities, on their ability to provide students with context and perspective that allow them to make sense of what they have observed or experienced.

The future of law schools, then, is to embrace their vocation as knowledge communities, to embed their JD and other educational programs within their larger mandate of aggregating, critiquing, and disseminating knowledge, and to pay attention to the challenge of rapid and profound changes in society and in law. I have identified four useful strategies that they have adopted to teach students to think like lawyers, to contextualize and critically evaluate their legal experiences, to adapt to change, and, especially, to learn how to learn.

22 Admittedly, optional curriculums are sometimes merely eclectic, rather than carefully structured, a concern I expressed strongly as principal author of the Consultative Group on Research and Education in Law, Law and Learning: Report to the Social Sciences and Humanities Research Council of Canada (Ottawa: Social Sciences and Humanities Research Council of Canada, 1983) at 47-59.

23 For a review of recent literature on experiential learning, and its extensive adoption in one law school, see Lorne Sossin, “Experience the Future of Legal Education” (2014) 51:4 Alta L Rev 849. See also William M Sullivan et al, Educating Lawyers: Preparation for the Profession of Law (San Francisco: Jossey-Bass, 2007). 
But is this enough? If law graduates have not mastered the practical competencies and specific bodies of substantive law prescribed by Canada's law societies, will they pose a risk to their clients, their colleagues, and their liability insurers? I doubt it. Indeed, there are good reasons to believe the contrary. None of the iconic architects of the English legal system, none of today's judges of the Supreme Court of Canada, and none of the members of the profession's governing bodies had legal educations that conformed to the law societies' prescriptions. Indeed, some of them had educations that could only be described as rudimentary, but they are revered. Many leading practitioners and academics never took courses in the specialized fields of law where they make their reputations, some of which (such as the Charter $^{24}$ ) did not exist when they were law students. Most skilled advocates, draftspersons, counsellors, and negotiators learned their trade on the job because mentors took the time to teach them. Evidence from the United States makes this amply clear. Graduates of leading law schools that prize scholarship, offer wide-open curricula, and emphasize thinking skills, theory, and interdisciplinarity, fare relatively well even in today's difficult legal labour market. They are far more likely to be hired (and for better jobs) than graduates of the other sort of schools, those whose faculty do not publish and whose curricula emphasize "basics” and "preparation for practice.”25 Likewise, the large consulting firms that compete successfully with law firms in many key markets tend to hire people on the basis of their intellectual abilities, not their professional "competencies."26

Nor should any of this be surprising: in most labour markets today, sophisticated and adaptable knowledge-workers with generic capabilities tend to fare much better than semiskilled workers with a limited repertoire of skills and know-how closely aligned to the current modus operandi of particular employers or trades. Indeed, studies of labour markets emphasize their polarization — the emergence of a privileged class of knowledge-workers in good jobs is paralleled by significant growth in employment in bad jobs in the service sector. $^{27}$ Although the analogy is far from perfect, it is possible to predict parallel developments in the market for legal services. Graduates of elite schools, with a broad array of intellectual skills, will continue to occupy privileged positions in elite firms and government and corporate law departments; "semi-skilled” general practitioners with workaday command of legal "basics" and routines will increasingly experience loss of

24 Canadian Charter of Rights and Freedoms, Part I of the Constitution Act, 1982, being Schedule B to the Canada Act 1982 (UK), 1982, c 11.

25 Recent publications have challenged the proposition that graduates of elite law schools earn enough to justify the high tuition fees they pay for the privilege of studying there. See e.g. Brian Z Tamanaha, Failing Law Schools (Chicago: University Chicago Press, 2012); Contra Ronit Dinovitzer, Bryant G Garth \& Joyce S Sterling, "Buyers' Remorse? An Empirical Assessment of the Desirability of a Lawyer Career” (2013) 63:2 J Leg Educ 1.

26 See e.g. "Careers,” online: McKinsey \& Company <http://www.mckinsey.com/careers/your_back ground $>$. McKinsey, a leading consulting firm, advised potential recruits on their website that

[o]ur consultants have been surgeons, scholars, and physicists. Entrepreneurs, government officials, and presidential speechwriters. Olympic athletes and cellists. There's a place for all types of people at McKinsey. Pick an academic degree, career background, or personal passion and chances are someone at McKinsey has it. Our diversity leads us to keener insights, innovative thinking, and sound solutions for our clients. Our wide range of expertise helps us tackle complex problems that don't fit into easily defined categories.

The language on their website has changed since it was first accessed in September 2013 but the point remains the same.

27 See e.g. David Autor, The Polarization of Job Opportunities in the U.S. Labor Market: Implications for Employment and Earnings (Washinton, DC: Center for American Progress and The Hamilton Project, 2010), online: MIT Economics < http://economics.mit.edu/files/5554>; Maarten Goos \& Alan Manning, "Lousy and Lovely Jobs: The Rising Polarization of Work in Britain" (2007) 89:1 Review of Economics and Statistics 118. 
market share, income, and professional influence; a new class of relatively low-paid legal service workers — paralegals — will emerge to perform much of the work formerly done by general practitioners. Indeed, it is possible to read Ontario's recent conscription of paralegals as members of the Law Society as a pre-emptive move by the bar to extend its regulatory reach over the new "legal service providers" who threaten the interests of its traditional core constituency of small firms and solo practitioners. ${ }^{28}$

What would such a reconfigured legal labour market imply for the future of law schools? If my original description of the legal profession as divided by deep fault lines is anywhere near accurate, and if those fault lines are likely to proliferate with the emergence of paralegals as an additional constituency within the profession, there will be strong pressures to ensure that each element of the profession is properly prepared for the unique tasks that it undertakes, much as in the medical profession. However, this can only be accomplished if this new system of educational credentials is explicitly linked to a new system of professional licensure, so that the scope of practice of each licensee is restricted to the areas in which she or he has received education and training. For example, general practitioners may one day be licensed to appear as advocates in certain tribunals and the lower courts, to execute routine real estate transactions and simple incorporations, and to process uncontested divorces, but not to undertake, say, appellate litigation, patent applications, tax planning, or other specialized tasks. Of course, the classes of membership would likely not be watertight: licensees in two or more classes might be eligible to perform some types of legal work; and members of each class would likely have the chance to requalify and enter a higher class.

If such a system of licensing were adopted — and the licensing of paralegals suggests that it may be - the future of law schools might look quite different from the one I have proposed. They might offer a skills-based one-year degree for paralegals, a stripped-down two-year "basic" degree for general practitioners, an enhanced four-year degree for specialist practitioners, and conversion courses for those who want to upgrade their credentials. This model has certain attractions: it would save time and money for those who wish to enter general practice, despite its declining prospects; it would ensure that legal specialists possess the theoretical, analytical, and contextual sophistication required to deal with complex and multidimensional issues; and it would enable law schools and other education providers to customize their curricula to fit the diverse needs of their students. These are definite advantages, but there are risks as well. A clear division between faculty members who teach "basics" to paralegals and general practitioners, and those who teach future legal specialists, intellectuals, and policy advisors is likely to engender squabbles over the soul of law schools, or at least over their budgets. There are risks for students too: stripping the generalist program down to "basics" might foreshorten the horizons and stunt the ambitions of the students enrolled in it. And there are risks for the profession: a system of limited licenses would force it not only to abandon the rhetoric of lawyers' omnicompetence, but to revisit policies and practices based on that rhetoric including the structures of professional governance, the code of professional conduct, the requirements for continuing education, and the provision of errors and omissions insurance. 
However, the risks are minimal. Law schools will not be redesigned to support a system of multiple professional credentials, because the profession is very unlikely to adopt such a system. At least for the foreseeable future, there will be only one proper professional credential - barrister and solicitor, and only one main route to obtaining that credential via an "approved" J.D. degree, one that ticks all the boxes specified in the new law society regulations. However, it will be difficult to tick those boxes if law schools remain true to their character as knowledge communities, if they persevere with scholarship, law reform, public advocacy, and graduate studies, and if they insist on giving J.D. students a liberal education in law. Law schools will somehow have to square this circle. They will either have to challenge the new regulations directly, or feign compliance and hope that no one notices. If they do neither, there will be more and more boxes to tick and less and less opportunity to do all the other things law schools should be doing. ${ }^{29}$

\section{CONCLUSION}

The future of law schools is uncertain: the social, political, and intellectual forces that shape law, legal practice, and legal education are in flux. Their future is contested; the academy and the profession are fundamentally at odds over the nature of knowledge, the best way to educate lawyers, and many other matters. And their future is plural: different law schools will have different futures. Nonetheless, I will venture a prediction. When this law school celebrates its bicentenary in $2113,{ }^{30}$ when speakers look back on its second century of accomplishment, they will mention distinguished scholarship more often than skills training, they will mention its long-term contributions to the public good more often than its immediate influence on present-day legal practice, and they will mention its role as an agent of change more often than its role as a faithful purveyor of conventional wisdom.

Taking the long view and focusing on change will seem like typical academic selfindulgence to those whose job it is to ensure that the public receives high quality professional services in the here and now. Describing law schools as multifunctional knowledge communities rather than institutions single-mindedly devoted to the training of practice ready lawyers will seem like callous indifference to the plight of students and recent graduates who face mounting debts and declining job opportunities. And my apparent downgrading of "hard law" and "how to" courses, and my privileging of theory and thinking, of interdisciplinarity and contextualization, will appall at least a few of my academic colleagues. To all of the above I apologize if, as they say, I have inadvertently given offence. But I am willing to bet that when the time capsule is opened 100 years hence, when someone removes the crumbling copy of my remarks and matches them against the historical record, I will turn out to have been right. And not only right, but helpful to those charged with upholding professional standards, prescient in my advice as to what kind of education will help students survive and flourish in volatile legal labour markets, and so modest in my prescriptions for reforming the law curriculum as to seem hopelessly conservative to my academic heirs and assigns.

\footnotetext{
29 I have developed this idea in some detail in "The Tree of Knowledge / The Axe of Power," supra note 3.

30 If indeed it does: see Harry W Arthurs, "Will the Law Society of Alberta Celebrate its Bicentenary?”
} (2008) 45:5 Alta L Rev 15. 